A Critical Assessment of Organic Agriculture in Portugal: A reflection on the agro-food system transition Isabel Salavisa Mark Soares Sofia Bizarro

Julho de 2021

WP n. $02021 / 05$

DOCUMENTO DE TRABALHO WORKING PAPER 


\section{dinamia 'cet_iscte}

A Critical Assessment of Organic Agriculture in Portugal: A reflection on the agro-food system transition

Isabel Salavisa*

Mark Soares**

Sofia Bizarro**

WP n. $\circ$ 2021/05

DOI: 10.15847/dinamiacet-iul.wp.2021.05

1. THEORECTICAL BACKGROUND

1.1. The Multi-Level Perspective (MLP) and Socio-Technological (ST) transitions theory... 3

1.2. Three extensions of the MLP-logic to conceptualise whole system reconfiguration of

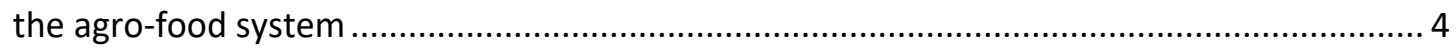

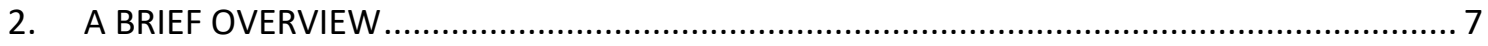

3. THE EVOLUTION OF THE ORGANIC SECTOR IN PORTUGAL IN COMPARATIVE TERMS ........ 11

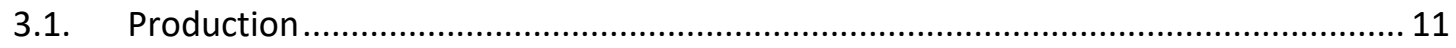

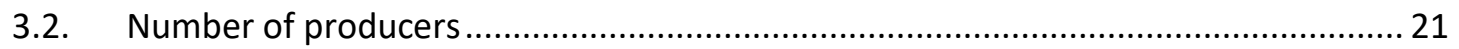

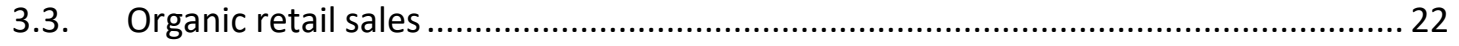

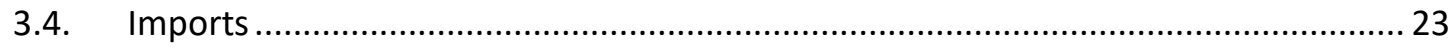

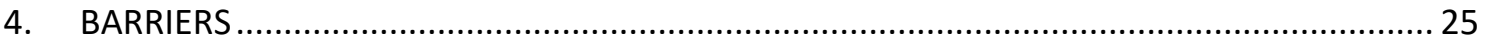

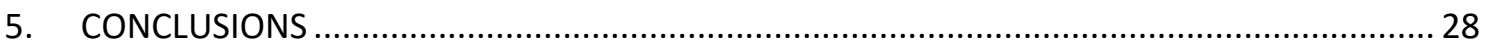

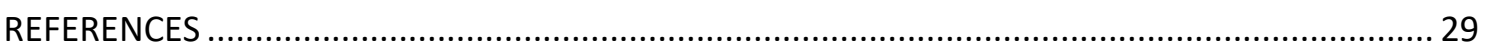

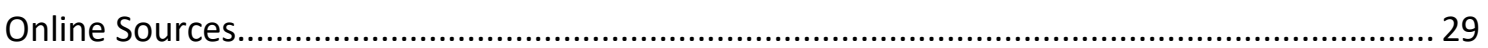

*ISCTE-IUL; DINÂMIA'CET-Iscte. Corresponding author: isabel.salavisa@iscte-iul.pt

**DINÂMIA-CET-Iscte 


\title{
A Critical Assessment of Organic Agriculture in Portugal: A reflection on the agro-food system transition ${ }^{1}$
}

\begin{abstract}
Over the last few decades, the organic agriculture sector has experienced sustained growth. Globally, as well as in the European Union and Portugal, organic production accounts for just under 10\% of total Utilised Agricultural Area (UAA) (FiBL, 2019; Eurostat, 2019; DGADR, 2019; INE, 2019; GPP, 2019). This growth has been seen in terms of production, number of producers, amount of retail sales, imports and exports.

This article attempts to build on the multi-level perspective (MLP) of the socio-technical (ST) transitions theory by employing a whole systems analysis (Geels, 2018) of organic agriculture in Portugal, which defends an integrated vision of the systems, where multiple interactions occur within and among the niche, the regime and the landscape levels. This approach has been employed in order to develop a critical analysis of the current state of the Portuguese organic agriculture sector, stressing the multiplicity of elements that are contributing to the agrofood system's transformation into a more sustainable one. In fact, the agro-food system is related with climate change but also has connections with other domains such as public health, water management, land use and biodiversity. Therefore, it is affected by shifts in these areas.
\end{abstract}

This analysis considers developments in increasing domestic organic production, number of producers, amount of retail sales, imports, exports, market innovations, and the sector's reconfiguration. The organic sector's increase has been attributed to European regulation, institutionalization, standardization, farmer certification, external (government) subsidy support programs, incremental market improvements (visibility and product access), the emergence of new retailers, the rise of supporting consumers and a shift away from conventional agriculture (Truninger, 2010; DGADR, 2019; Pe'er et al, 2019). However, together with positive incentives, this sector also faces numerous barriers that are hindering a faster transformation.

\footnotetext{
${ }^{1}$ Research was carried on the SPLACH Project - Spatial Planning for Change - POCI-01-0145-FEDER-016431, financed by the European Regional Development Fund (FEDER), through COMPETE2020 - Competitiveness and Internationalization Operational Program (POCI) and by National funds through the Foundation for Science and Technology - FCT (2017-2021), within DINAMIA’CET-Iscte.
} 
Difficulties for the sector to date have included: product placement; a disconnect between production, distribution and marketing systems; high transport costs; competition from imports; European subsidies focused on extensive crops (pastures, olive groves, and arable crops), entailing a substantial growth in the area of pasture to the detriment of other crops; the fact that the products that are in demand (fresh vegetables and fruit) are being neglected by Portuguese producers; expensive certification procedures; lack of adequate support and market expertise for national producers; the hybrid configuration of the sector; and price. Organic agriculture as a niche-innovation is still not greatly contributing to overall agricultural production. The low supply of organic products, despite its ever-increasing demand, suggests that a transition to increased organic production requires a deeper and faster food system reconfiguration, where an array of distinct policies are mobilized and a diversity of actions take place at different levels (Geels, 2018; Pe'er et al, 2019).

This paper will attempt to contribute an overall critical assessment of the organic sector's features and evolution and will identify some of the main obstacles to be overcome, in order to boost the sustainability transition of the agro-food system in Portugal.

Key words: organic agriculture; sustainability transitions; systems reconfiguration; agro-food system.

\section{THEORECTICAL BACKGROUND}

\subsection{The Multi-Level Perspective (MLP) and Socio-Technological (ST) transitions theory}

This article attempts to build on the Multi-Level Perspective (MLP) of the socio-technical (ST) transitions theory by employing a Whole Systems Analysis of the sustainability of the Agro-food system - organic agriculture in Portugal (Geels, 2018).

The analysis aims to broaden the MLP so that it analyses not just one, but multiple niche innovations, regimes and their associated interactions at the three MLP levels (Geels, 2018, p.87). This is as the MLP employs an integrated vision of the systems, where multiple interactions occur within and among the landscape, the regime and the niche levels (Geels, 2018, p.87).

The MLP may be broadened by employing a Whole System Analysis of the agro-food system. Such an analysis may "focus on multiple commodity regimes (wheat, fruit, pork, beef, dairy, coffee), which are often organised as international chains (input suppliers, farmers, 
processors, retailers, consumers), in which supermarkets have powerful coordinating positions" (Geels, 2018, p.87).

The agro-food system, like other systems, is complex as it contains multiple production regimes, that is, industrialized agriculture, organic farming, and integrated production (Belz, 2004). Industrialized agriculture dominates in Portugal, whereas organic agriculture and integrated production remain "subaltern regimes" (Geels, 2018, p.87), that are much smaller in terms of total area and amount of production (DGADR, 2019).

Here, the Whole System Analysis MLP approach is employed to critically analyse the current state of the Portuguese organic agriculture sector. The aim is to extend the MLP to analyse a whole system reconfiguration of the Portuguese Agro-food system, and to take stock of the reconfiguration potential of this system. This is done by stressing the multiplicity of elements that are contributing to the agro-food system's transformation into a more sustainable one. In fact, the agro-food system is connected (affects and is affected) with climate change, public health, water management, land use biodiversity, and other areas (Geels, 2018, p.87).

\subsection{Three extensions of the MLP-logic to conceptualise whole system reconfiguration of the agro-food system}

\section{1) Multiple landscape dynamics differentially affect agro-food regimes}

Macro-ideologies at the landscape level may shape the agro-food system's sustainability transition. This is as, according to Geels (2018) "variable effects of landscape dynamics depend on their specific translation into different regimes", which are "at least partly shaped by macroideologies at the landscape level" (Geels, 2018, p.88). For example, neo-liberalism shaped UK policymaker responses with respect to climate change and the financial crisis and thereby affected government spending with respect to passenger mobility in The UK (Geels, 2018, p.88), and it may have done the same for the agro-food system.

Via whole system analysis, the trajectories of a regime may not be well aligned, which may result in the transition going in the "wrong direction" (Geels, 2018, p.88). For example, with respect to the agro-food system's sustainability transition, if the regime is not well-aligned, a transition to more organic production and away from industrialized production may in fact go in the "wrong direction" (i.e. away from greater sustainability) as it could end up "leading to higher CO2 emissions" (Geels, 2018, p.88). Thus, a lack of regime alignment can result in a transition that acts contrary to the agro-food system's desired transition towards a sustainable food system. 


\section{2) Internal regime dynamics and multi-regime interactions}

According to Geels, the MLP suggests that:

- "Existing regimes are not static or inert, but 'dynamically stable' (...), with reproduction and modification of rules leading to incremental changes in system components (e.g. technology, markets, policy). Continuous incremental change may, over time, lead to substantial performance improvements that can lower C02 emissions", for instance. (Geels, 2018, p.88).

- "Regime actors", (e.g. "firms, policy-makers, users, wider publics") (Geels, 2018, p.88), are influenced by various motivations (e.g. profits, accessibility, congestion, safety, convenience, affordability, air quality) that "influence strategies and innovation activities" (Geels, 2018, p.88).

- "Because [agro-food] systems consist of multiple [agro-food] regimes, system reconfiguration may also occur via interactions between multiple regimes". Multi-regime interactions include:

"Competition between regimes may lead to shifts in relative size, e.g. a `modal shift' from cars to trains" (Geels, 2018, p.88). In the case of this study on the agro-food system, a modal shift from industrial agriculture scale sized plots to organic agriculture scale sized plots may result;

"Symbiosis between regimes means that they positively interact, but remain relatively separate" (Geels, 2018, p.88). With respect to the agro-food regime, a shift towards organic agriculture, for instance, may create symbiotic linkages between industrial food production and organic food production regimes, along with transportation (distribution) and market (e.g. supermarket) regimes;

"Integration [between regimes] means that regimes interact closely to form a new system" (Geels, 2018, p.88). For instance, the agro-food system's dominant industrial regime appears to be interacting closely with the emerging sub-altern organic regime. This is, as some observers suggest, that the niche organic innovation is being co-opted by and integrated into the dominant industrial regime. This is resulting in a new Agro-food system where industrial, organic and integrated production are integrated together at the regime level (Geels, 2018, p.88; Belz, 2004).

- "Systems are not closed, but influenced by broader systems. The reason is that mobility is (largely) a 'derived demand', which supports other social practices such as leisure, visiting friends, shopping, commuting to work, business travel, bringing children to school." (Geels, 2018, p.88). "Mobility demand is therefore strongly shaped by developments in non-transport regimes 
(e.g. work, retail and spatial planning) and by socio-economic landscape developments (e.g. economic growth, demographics)." (Geels, 2018, p.88). So too, are agro-food regimes shaped by non-agro-food regimes (e.g. tourism, housing development - a driver of urban-sprawl, and spatial planning) and by socio-economic landscape developments (e.g. economic growth, demographics).

\section{3) Multiple niche-innovations}

It is possible that agro-food system reconfiguration is "likely to involve multiple nicheinnovations which may affect ... [agro-food] ... regimes through different mechanisms" (Geels, 2018, p.88). These different mechanisms may include technological niche-innovations that:

• "may replace existing components" (Geels, 2018, p.88), (e.g. organic production methods may replace industrial agricultural methods in agro-food production);

- "can be symbiotically adopted in existing regimes, leading to hybrid forms" (Geels, 2018, p.88). For example, organic food products may be produced alongside industrial food products by the same producers and in the same manner (i.e. large-scale mechanized monoculture production). Also, organic products can be adopted by large supermarket chain stores - the dominant retail regime - and incorporated onto their shelves alongside non-organic products);

- "may improve existing regimes or create new linkages between regimes" (Geels, 2018, p.88), (e.g. urban organic agriculture that shortens the distance food must travel to consumers by connecting to local farmers markets and specialty food stores);

- "in non-[agro-food] regimes that affect [food] demand" (Geels, 2018, p.88) (e.g. biofuel, climate change, public health, water management, land use and biodiversity regimes all affect the agro-food regime). For example, biofuels - as a non-agro-food regime - are a niche-innovation in the energy regime that can affect food demand and thus the agro-food regime.

The agro-food system can transition to organic agricultural production through the change of multiple mechanisms.

Figure 1 offers a whole system reconfiguration representation of the agro-food system as it combines the three MLP levels and their extensions (Figure 1). 
Figure 1: An Integrated MLP representation of the agro-food system reconfiguration

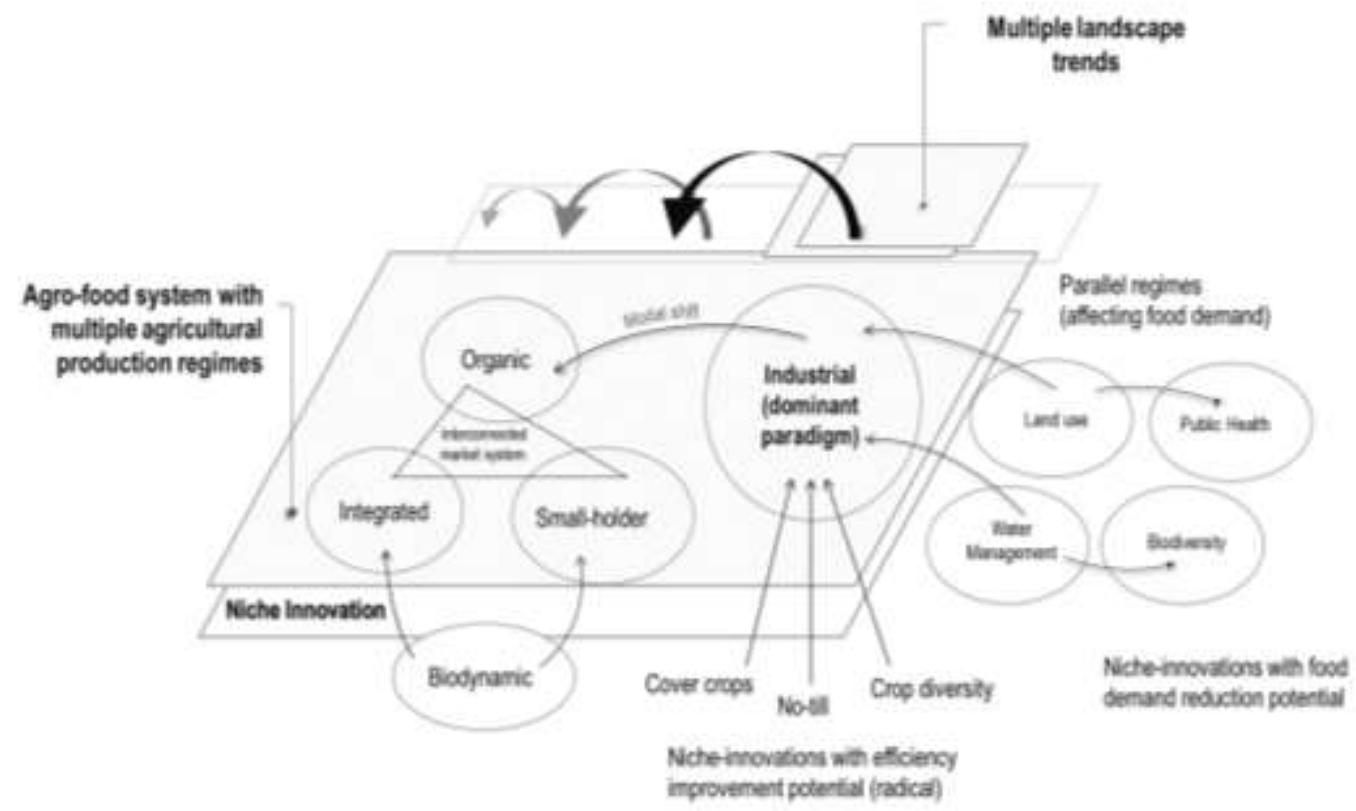

Source: Adapted by the Authors to the Agro-food system, from Geels, 2018, p.88, Fig.1 (Integrative MLPconceptualisation of passenger mobility system reconfiguration).

\section{A BRIEF OVERVIEW}

Overall, since 1994 the organic agriculture sector has grown in Portugal. According to Truninger (2010), Matos et al (2016), the DGADR (2019), and Pe'er et al (2019), its increase may be attributed to the following drivers:

i) EU Regulations, Strategies and Plans governing the organic sector in Portugal ${ }^{2}$, which include:

- Regulation (EC) No. 2092/1991 - EU standard that was transposed into national codes in 1993. (Truninger, 2010, p.207), replaced in 2009 by (EC) No.834/2007;

- Regulation (EC) No. 2078/1992 - concerned with financial incentives for the conversion of conventional farms to organic production - refers to CAP reform package (Truninger, 2010, p.91);

- Regulation (EC) No. 223/2003 - criteria for labelling and control of animal production and animal feed (Truninger, 2010, p.91);

\footnotetext{
${ }^{2}$ More information on legislation is available: https://www.dgadr.gov.pt/sustentavel/modo-de-producao-biologico
} 
- Regulation (EC) No. 834/2007 - the legal framework for all levels of production, distribution, control and labelling of organic products marketed in EU member states (Truninger, 2010, p.91);

- Regulation (EC) No. 889/2008 - detailed rules for the implementation of the legal provisions for organic production, labelling and control; and

- Regulation (EC) No. 967/2008 - mandatory use of the EU organic logo (Truninger, 2010, p.91). Taken together, these regulations led to the legalization of organic farming practices;

- Regulation (EC) No. 848/2018 of the European Parliament and of the Council of 30 May 2018 on organic production and labelling of organic products.

In addition, over the years, various strategies and plans have been developed in the EU to complement the above legislation. These have included the European Action Plan for Organic Farming (2004), and the Plan for the future of Organic Production in the European Union $(\mathrm{COM}(2014) 179))$. Each EU Member State has processed and adapted these strategies to form national regulations. In Portugal, the National Strategy for Organic Farming (2017) (Resolução do Conselho de Ministros n. ${ }^{\circ}$ 110/2017 - Estratégia Nacional para a Agricultura Biológica $(\mathrm{ENAB}))$ was created to define the strategic actions that are to be taken by the sector.

ii) Institutionalization: has developed the market and attracted new farmers, investors and retailers (Truninger, 2010, p.207). It started in 1985 with the founding of an official national association of organic farming - "Agrobio" - to institutionalize the movement (Truninger, 2010, p.86). In addition, organic farming fairs (e.g. Terra Sã - Fair of Biological Agriculture, Environment and Quality of Life) provided a meeting point for institutions, market players and consumers to exchange ideas, discussions, initiatives, and to sell and buy organic products (Truninger, 2010, p.87). Also, farmer campaigns (e.g. One thousand partners) helped to recruit more members (FiBL, ${ }^{3}$ 2019);

iii) Standardization: has led to market development and investor and retailer interest. IFOAM principles, values and standards of good practice were first followed by Agrobio until the adoption of EU standards as laid out in regulations (Truninger, 2010, p.88);

iv) Farmer certification: Independent organic certification and control bodies have been set up as per EU requirements (e.g. Socert in Portugal) (Truninger, 2010, p.87; FiBL, 2019);

v) External (government) subsidy support programs: The `Package of agro-environmental measures' linked with the EU's 'Common Agricultural Policy (CAP)', allowed financial

\footnotetext{
${ }^{3} \mathrm{FiBL}$ - The Research Institute of Organic Agriculture - was founded in Switzerland in 1973 and is an independent, non-profit, research institute that is committed to the international development of organic agriculture. FiBL conducts cutting-edge science, knowledge transfer, consulting, advisory work, training courses and expert reports on organic agriculture. Its centres are located in Switzerland, Germany, Austria, and France. It works closely with the International Federation of Organic Agriculture Movements (IFOAM) and other international organisations. In Eastern Europe, India, Latin America and Africa, it promotes organic research, advisory services and certification services. Source: https://www.fibl.org/en/about-us.html
} 
resources for converting land to organic farming, and for subsidies to draw in large number of farmers to organic farming, thereby growing the market (Truninger, 2010, p.207; Matos et al, 2016, p.26);

vi) Incremental market improvements: Have been achieved by: addressing domestic demand a sustainable entrepreneurship producer group (pioneers of the movement) has aimed to address domestic demand and the collective development of the sector; and via export orientation and specialization - a second group (neophytes) neglects what consumers most want to buy (e.g., fruits and vegetables) to develop the sector in a profitable and dynamic way via European subsidies and by using technically less demanding and labour intensive types of production. This group has increased production of certain types of crops (e.g. olive groves for organic olives/oil, pasture for organic livestock) thereby following a monoculture industrial production model (see point viii for retailer role in increasing visibility and product access) (Truninger, 2010, p.207). Producer organizations have formed to "achieve scale, create their own marketing channels and adopting different strategies" (Matos et al, 2016);

vii) Market innovations: Specialty retail outlets specializing in macrobiotic, dietary and health products started a market for organic products in Portugal in the 1970s (Truninger, 2010, p.82). These retailers led to organic products fetching/getting higher prices on the market thus leading to higher economic profitability (Truninger, 2010, p.207). Furthermore, conventionalization due to consolidation by large supermarket chains has driven the commercialization of organic products, thereby increasing the diversity of organic products as well as the volume of sales (Truninger, 2010, p.207; Matos et al, 2016);

viii) Retailers: Small and medium sized retailers (small markets, fairs, specialty shops, small supermarkets) promote short food lines and proximity trade (Truninger, 2010, p.207). In contrast, large supermarket chains (which own a large share of the organic market) have: developed largescale trade (long distribution lines to goods and to distant consumers), disseminate and advertise organic products by placing them on shelves with frequency, volume and variety; and better organize and structure the sector's operations (logistics, direct hiring of national producers, clarification of packaging \& marketing criteria, more shelf space with visible signage and distinct labelling) (Truninger, 2010, p.82, 207; Matos et al, 2016);

ix) Consumers: initially, there existed a lack of consumer demand for organic products and the sector was forced to grow by community financial incentives. Consumer demand did eventually increase, especially after various food scandals (mad cow disease; dioxins in chickens; bird-flu; swine-flu; and uncertainty over products containing genetically modified organisms - GMOs) led to greater risk perception among the population. These scandals and the way official bodies dealt 
with them have sparked an interest in higher quality food products among some consumers (Truninger, 2010, p.91);

x) A shift away from conventional agriculture (i.e. the sector's reconfiguration): EU rural development policies included agro-environmental measures linked to financial resources for organic farming - these attracted new farmers to the sector (Matos et al, 2016). Furthermore, The European Action Plan for Organic Farming (2004) defined 21 actions for EU member countries to develop the market through information, to increase public support for organics, and to improve rules on farming and controls on import requirements (Truninger, 2010, p.92). Also, the National Sustainable Development Strategy (ENDS) has applied the European Sustainable Development Strategy’s main points in Portugal.

Over the last two decades, the support schemes provided by the EU rural development programme (i.e. RURIS (2000-2006), PRODER (2007-2013), and PDR (2014-2020)) encouraged the development of organic farming activities in Portugal, as they provided very important financial support to the sector (EU-EC H2020, 2020). More recently, the Action Plan for the future of Organic Production in the European Union (COM(2014)179) focused on three priority domains for the Horizon 2020 vision: "The first one is to increase competitiveness of European Union organic producers [...] The second priority domain is consolidating and increasing consumer confidence in the European scheme for organic food and farming, as well as trust on the organic products imported, in particular as to the control measures. The third priority domain is to reinforce the external dimension of the EU organic production scheme." (EU-EC, 2014, p.4). This strategy displays the consolidated position of organic agriculture in the EU market. However, accomplishing these future goals requires: a revised support measures scheme; legal frameworks, improving the articulation between sub-programs; and coherence with other EU policies. Particularly, the post-2020 Common Agricultural Policy (CAP) should target organic farming in a broad approach to address environmental and climate issues, as incorporating organic farming may contribute to the achievements of multiple social, economic and environmental domains $^{4}$ (Horizon 2020 - Work Programme - European Commission Decision C(2019)7814 of 30 October 2019).

\footnotetext{
${ }^{4} 2020$ Biodiversity Strategy - $\operatorname{COM}(2011)$ 244, the Green Infrastructure Communication - SWD(2013) 155 , Soil Thematic Strategy COM(2006)231, the Birds and Habitats Directives - Directive 2009/147/EC/ Directive 43/92/EEC, the Nitrates Directive - Directive 91/676/EEC, the Water Framework Directive - Directive 2000/60/EC, the National Emission Ceiling Directive - Directive 2001/81/EC).
} 


\section{THE EVOLUTION OF THE ORGANIC SECTOR IN PORTUGAL IN COMPARATIVE TERMS}

\subsection{Production}

\subsubsection{Utilised Agricultural Area in Hectares and Percent (\%)}

Portugal has roughly $7 \%$ of its Utilised Agricultural Area (UAA) under organic production (Eurostat, 2019). The country's growth has been slow, going from 214,442 ha in 2008 (5.7\% of UAA) to 253,786 ha in 2017 (7\% of its UAA) (Figure 3) (Eurostat, 2019). Thus, it has failed to have its organic area reach $10 \%$ of UAA.

The first records of organic farming date back to 1994 (DGADR, 2017, p.11). The largest increases took place in 2000-2007, as the area increased from about 50,000 to 229,717 hectares (perhaps aided/driven by the Ruris program) (DGADR, 2017, p.11). From 2008-2013, there were successive decreases as at the end of this period there was approximately $-15 \%$ less organic area (197,295 ha) than there was at the start of this period (229,717 ha) (DGADR, 2017, p.11; Eurostat, 2019). This variation resulted from changes in production support programs and from a change in the methodology used for collecting statistical information. This shift is shown by a break in the trend line for number of producers between the years 2009 and 2010 in Figure 2 (DGADR, 2017, p.11).

Figure 2: Utilised Agricultural Area (UAA) under Organic Agricultural Production (ha) and Number of Organic Producers in Continental Portugal (1994-2017)

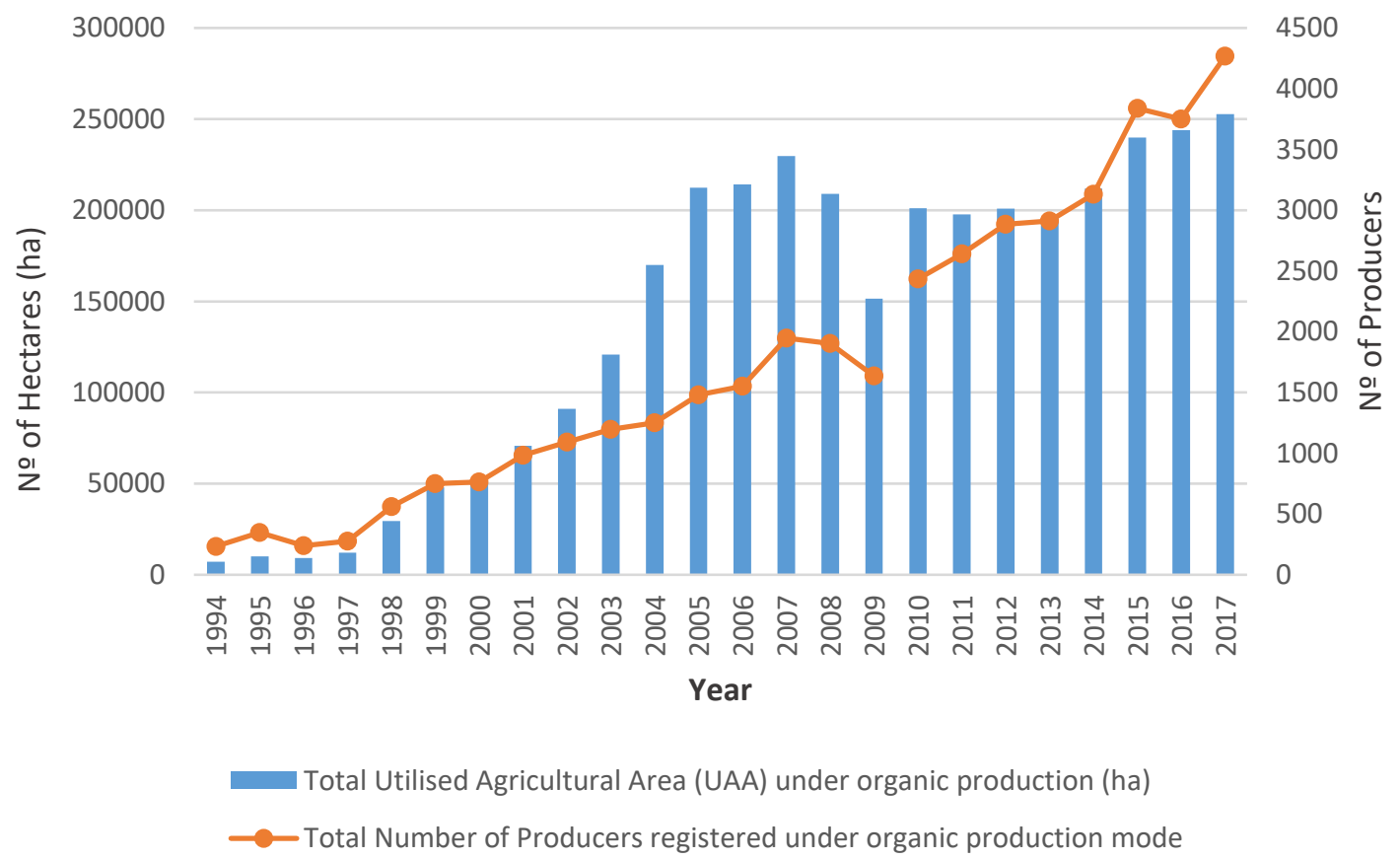

Source of data: DGADR, 2018. (Note: From 2010 onwards the DGADR utilized a new methodology to calculate values, this is why there exists a break in the series). 
Overall, increases in organic production area may have been the result of the support schemes that existed for organic production at the time, such as the current PDR 2014-2020 program (Avillez, 2015, p.93).

Next, looking at the regional distribution in 2017, the total organic UAA of 252,812 ha (continental total without forest area) was distributed as follows: Alentejo (155,219 ha; $61 \%)$, Beira Interior (45,691 ha; 18\%), Ribatejo e Oeste (21,536 ha; 9\%), Trás-os-Montes (18,228 ha; 7\%), Entre-Douro e Minho (8,589 ha; 3\%), Beira Litoral (2,236 ha; 1\%), and Algarve (1,313 ha; 1\%) (DGADR, 2019; DGADR, 2019, p.13). The Alentejo with the Beira Interior accounted for 79\% of organic UAA in 2017 (Figure 3) (DGADR, 2019, p.7).

Therefore, as can be seen in Figure 3, the general growth trend at the regional level in Portugal was positive from 1994 to 2008. From 2009 to 2016, based on the newly delineated agricultural regions breakdown in Portugal, most regions roughly doubled their UAA under organic production (DGADR, 2017, p.12). The Lisbon Metropolitan Area (AML) only managed to increase its own production by $0.6 \%$ in this period (only the Algarve was worse with $0.3 \%$ ), suggesting that the AML is lagging behind (Table 1) (INE, 2009, 2013, 2016; DGADR, 2017, p.12).

Figure 3: Proportion of UAA under Organic Agriculture (ha) by Agricultural Region (1994-2015)

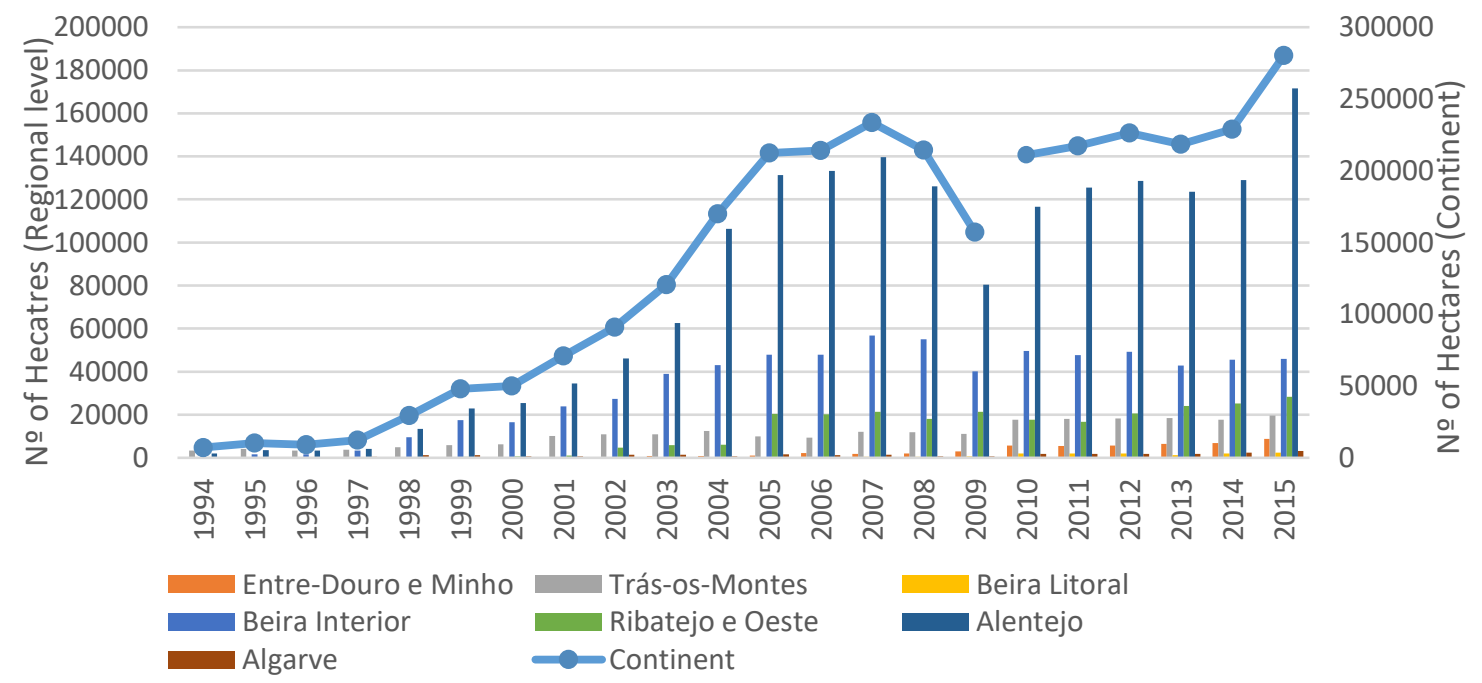

Source of data: DGADR, 2019. Link: https://www.dgadr.gov.pt/sustentavel/modo-de-producao-biologico. (Note: From 2010 onwards the DGADR utilized a new methodology to calculate values, this is why there exists a break in the series). 
Table 1: Utilised Agricultural Area (UAA) in organic mode of production in \% by Agricultural Region (2009, 2013, and 2016)

\begin{tabular}{|l|r|r|r|}
\hline \multicolumn{1}{c|}{$\begin{array}{c}\text { GEOGRAPHIC LOCATION } \\
\text { (NUTS 2013) }\end{array}$} & $\mathbf{2 0 0 9}$ & $\mathbf{2 0 1 3}$ & \multicolumn{2}{c|}{$\mathbf{2 0 1 6}$} \\
\cline { 2 - 4 } Portugal & $\boldsymbol{\%}$ & $\boldsymbol{\%}$ & $\boldsymbol{\%}$ \\
\hline Continent & 2.7 & 3.9 & 5.1 \\
\hline North & 2.8 & 4.0 & 5.3 \\
\hline Centre & 1.2 & 2.1 & 2.0 \\
\hline Lisbon Metropolitan Area $(\boldsymbol{A M L})$ & 4.6 & 6.1 & 7.2 \\
\hline Alentejo & 1.2 & 1.7 & 1.8 \\
\hline Algarve & 2.9 & 4.2 & 6.2 \\
\hline
\end{tabular}

Source of data: INE, 2009, 2013, 2016.

Taking a look at the EU28, about 7\% of its UAA was under organic production in 2017 (Eurostat, 2019). For the EU28, the same trend of continued growth in organic UAA has held true from 2012 to 2018 (Figure 4) (Eurostat, 2019; DGADR, 2017, p.60).

Figure 4: Percent of EU28`s UAA under organic production (2012-2018).

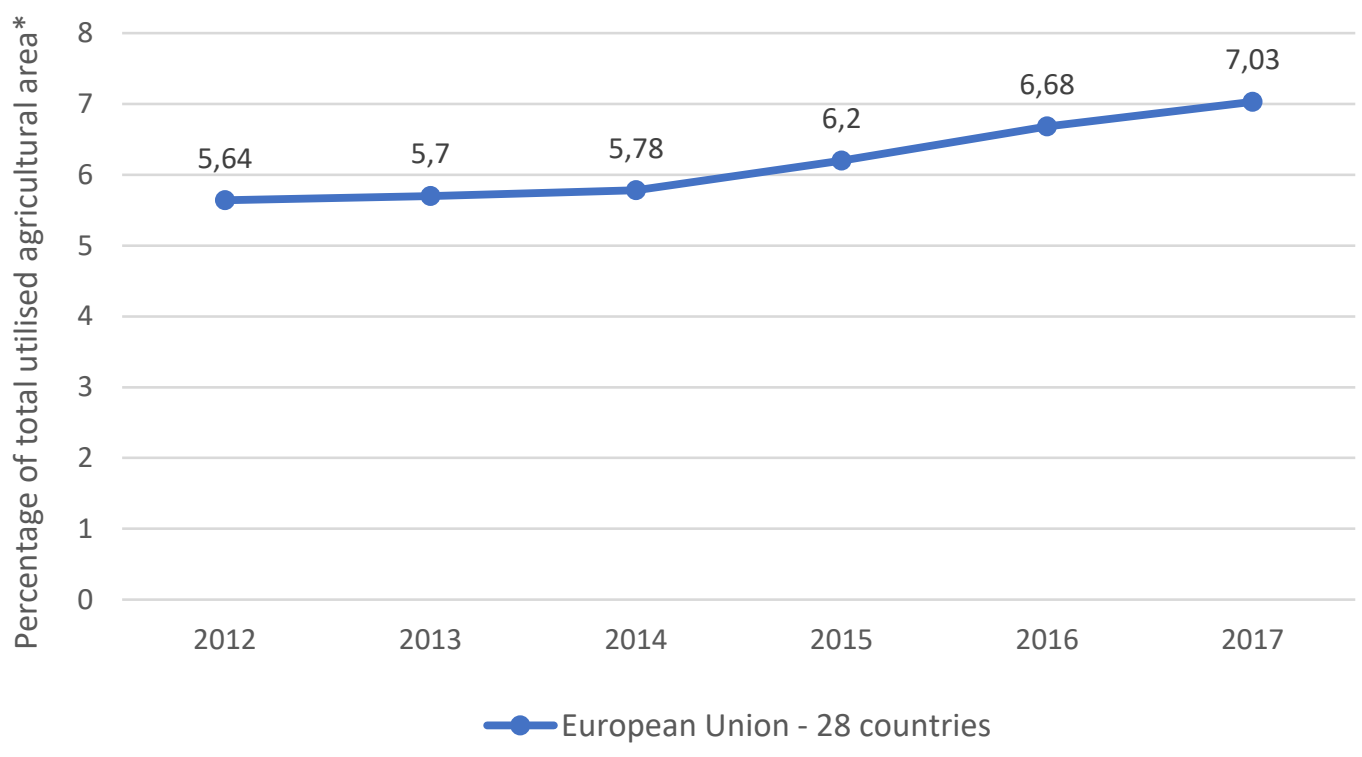

*Total UAA excludes kitchen gardens while it includes total fully converted and under conversion to organic farming

Source of data: Eurostat, 2019. 
Moving on down to the country level, the trend of growth in total organic area for the EU Member States is evident in Figure 5 which compares values for 2012 with those of 2017 for each member state in hectares.

Figure 5: Total organic area in hectares (fully converted and under conversion) by country, 2012 and 2017 (EU28 countries, 3 non-member countries and 3 candidate countries)

2500000

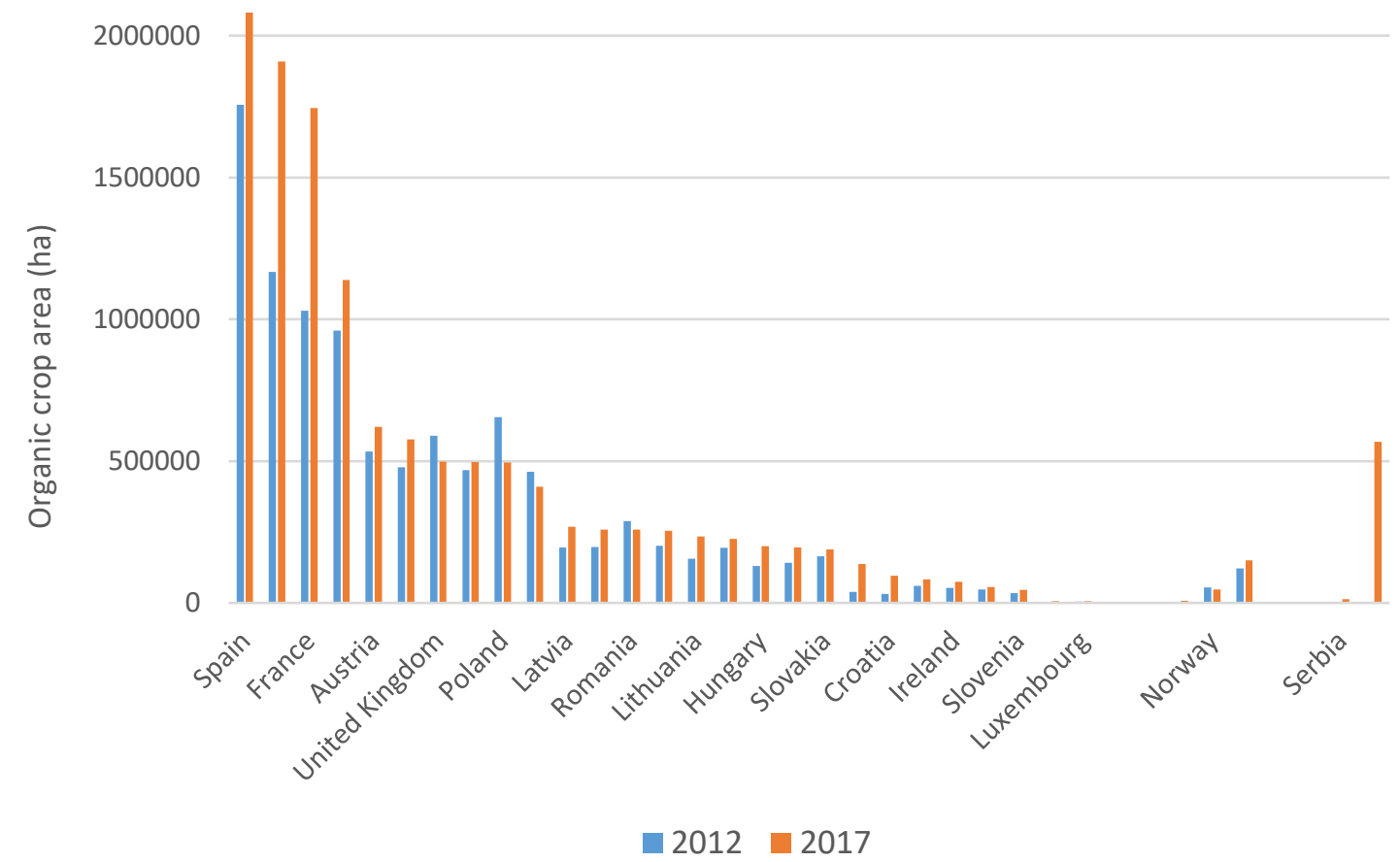

Source of data: Eurostat, 2019.

In terms of share of total organic area in a Member State's total utilised agricultural area (UAA), Portugal ranks fourteenth amongst EU28 countries (Figure 6). 
Figure 6: Share of total organic area (\%) in total utilised agricultural area (UAA), 2017 (EU28 countries, 3 non-member countries and 3 candidate countries)

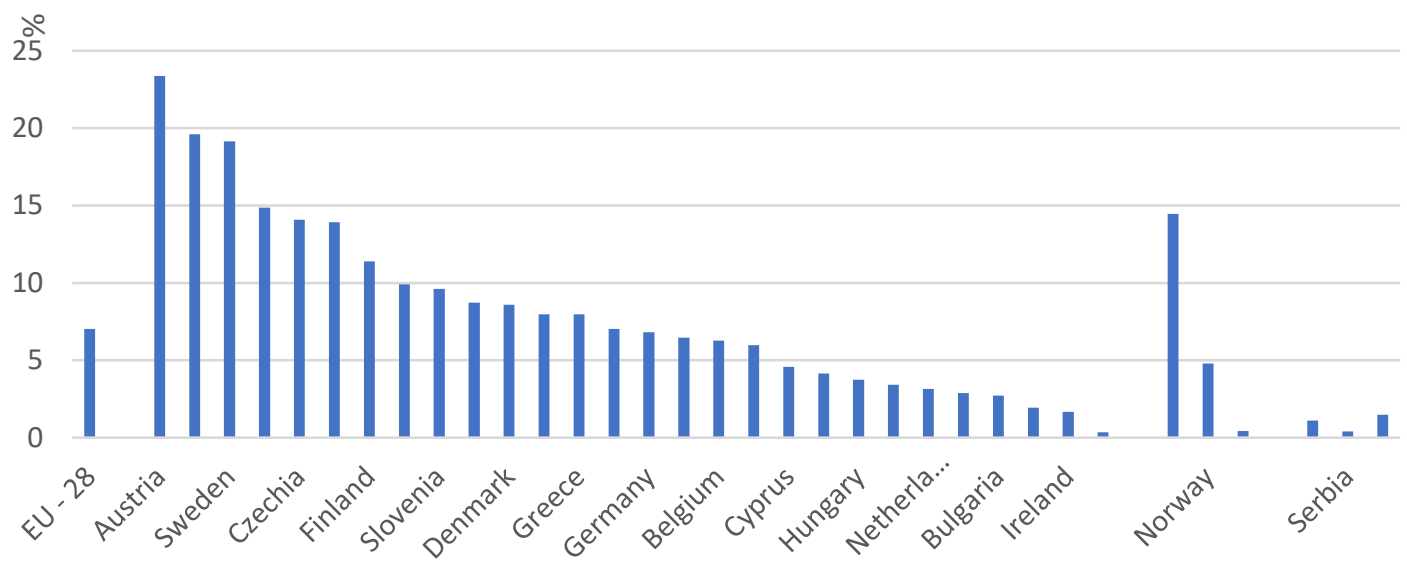

Source of data: Eurostat, 2019.

Out of the total organic area in the EU28, Portugal ranks outside the EU28's top 10 Member States. This is as four Member States accounted for more than half $(54.7 \%)$ of all organic farmland in the EU28 in 2017: Spain 2,082,173 ha (16.6\%), Italy 1,908,570 ha (15.2 \%) France $1,744,420$ ha (13.9\%) and Germany 1,138,272 ha (9.1\%) (Figure 7). (Eurostat, 2019).

Figure 7: Share of the EU28's total organic area possessed by each Member State in 2017 in

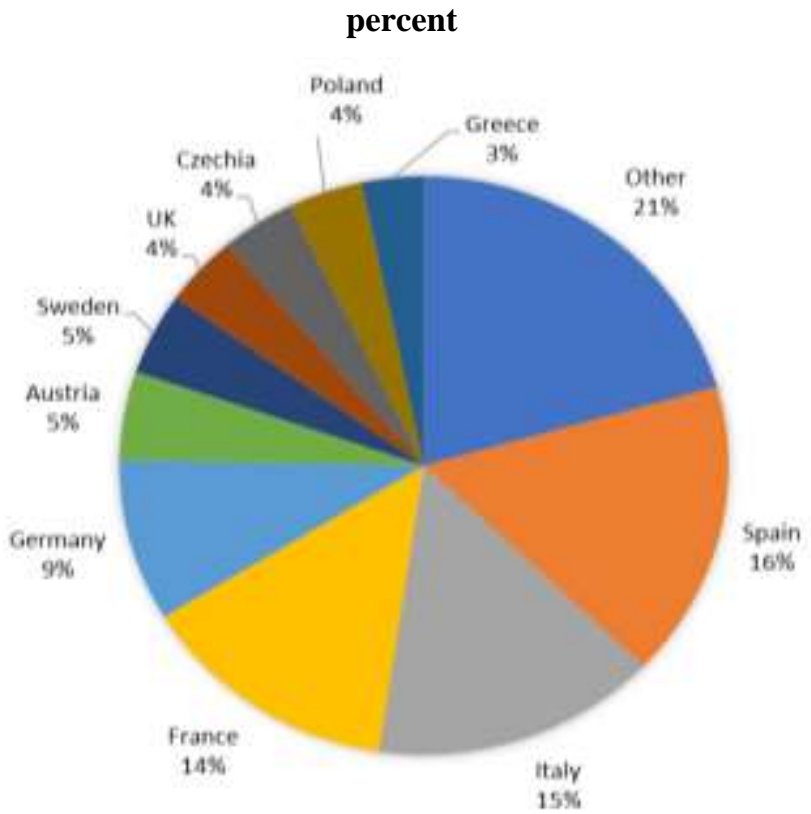

Source of data: Eurostat, 2019. 
Globally, organic agricultural production has also experienced sustained growth. For example, it is estimated that from 2008-2017, the number of hectares (fully converted + under conversion) in organic production has slightly more than doubled (roughly estimated to have gone from 34 million ha, in 2008, to 70 million ha, in 2017) (FiBL, 2019). Out of each region's total UAA the percentage under organic agriculture in 2017 was: Oceania (8.55\%), Europe (2.90\%), Latin America (1.06\%), North America (0.79\%) (the USA, 0.59\%), and Asia (0.38\%) (FiBL, 2019).

Thus, despite the sector's growth, organic production still does not account for $10 \%$ of the total UAA anywhere, as it fails to do so in Portugal, in Europe (as well as in the EU), in the other continents, and globally.

\subsubsection{Crops: UAA by Type of Crop in Percent (\%)}

Of Portugal's total UAA under organic farming (252,812 ha without forested land), the area was being used for: pasture (58\%), forage/fodder crops (14\%), dried fruits (9.7\%), olive trees $(8.6 \%)$, arable crops (2.9\%), fallow (2.4\%), fruit growing (1.6\%), vineyards (1.4\%), horticulture $(1.2 \%)$, and aromatic plants $(0.3 \%)$ (DGADR, 2019). Taken together, pasture, forage crops and dried fruits accounted for $81.7 \%$ of the area under organic farming in 2017 (DGADR, 2019, p.12, 19). Out of the total, $72 \%$ was pasture and fodder that was being grown to feed livestock, while just $26 \%$ (of the total area) was being used for the production of food products (for direct food consumption or for processing) (Figure 8) (DGADR, 2019, p.12).

Figure 8: Area Under Organic Agriculture by Type of Crop in Portugal in percent (\%) for 2017

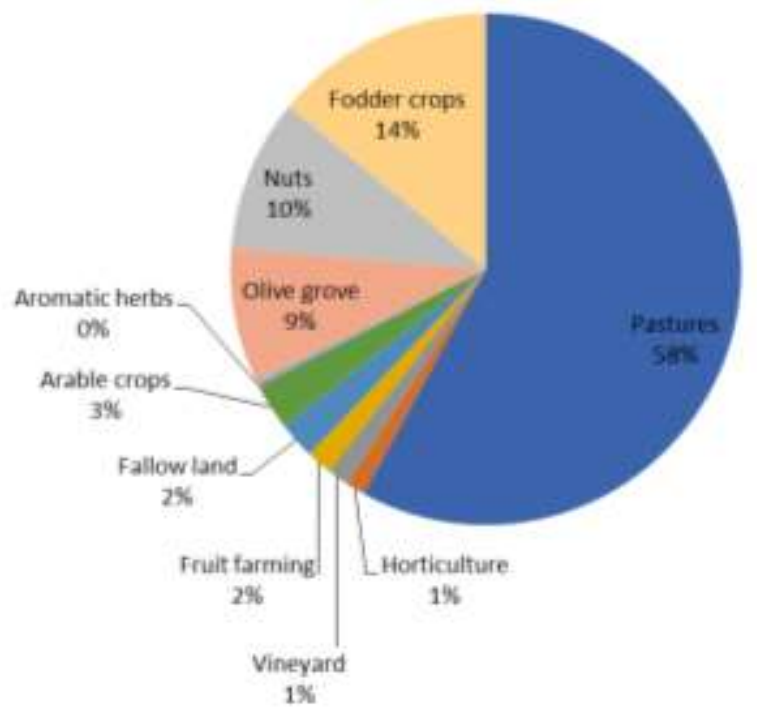

Source of data: DGADR, 2018. 
Furthermore, the large majority of the crops have been mainly cultivated in the Alentejo and Beira Interior (Figure 9). This is a product of the agroecological characteristics of these regions and the fact that farming in general has a high weight in these regions (DGADR, 2017, p.20).

Figure 9: Proportion of the organic UAA total (\%) held by each agricultural region in Continental

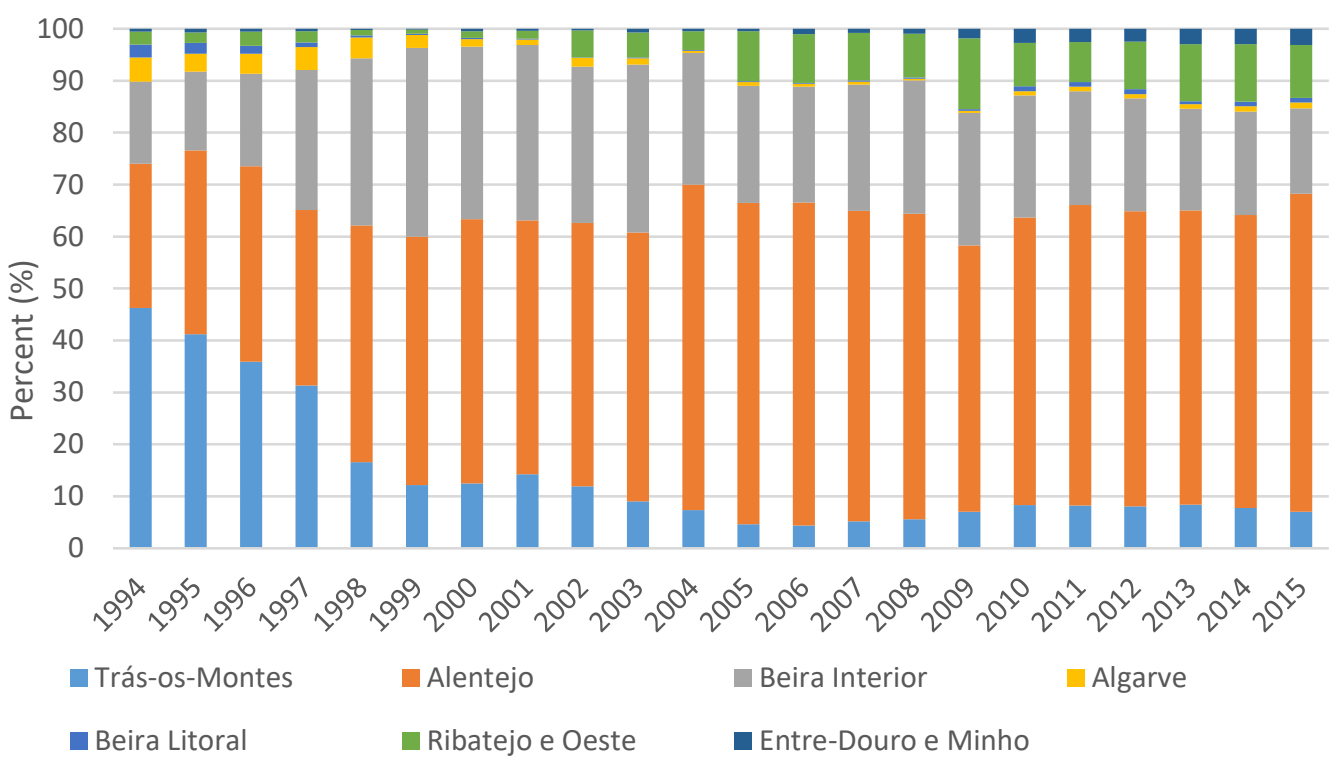

Source of data: DGADR, 2019.

Turning to the EU28, in 2017, the total organic UAA of 5.5 million ha was broken down into arable land (44.5\%), pastures and meadows (44.4\%) (mostly grazing land for organic livestock), and permanent crops (11.0\%). (Eurostat, 2019). In 11 EU Member States, more than $50 \%$ of the organic area was arable land crops, while in 13 Member States more than $50 \%$ of the organic area was pastures and meadows (Figure 10) (Eurostat, 2019). 
Figure 10: Percentage of total organic UAA broken down into arable land crops, permanent grassland (pastures and meadows) and permanent crops in 2017 (EU28 countries, 3 non-member countries and 3 candidate countries)

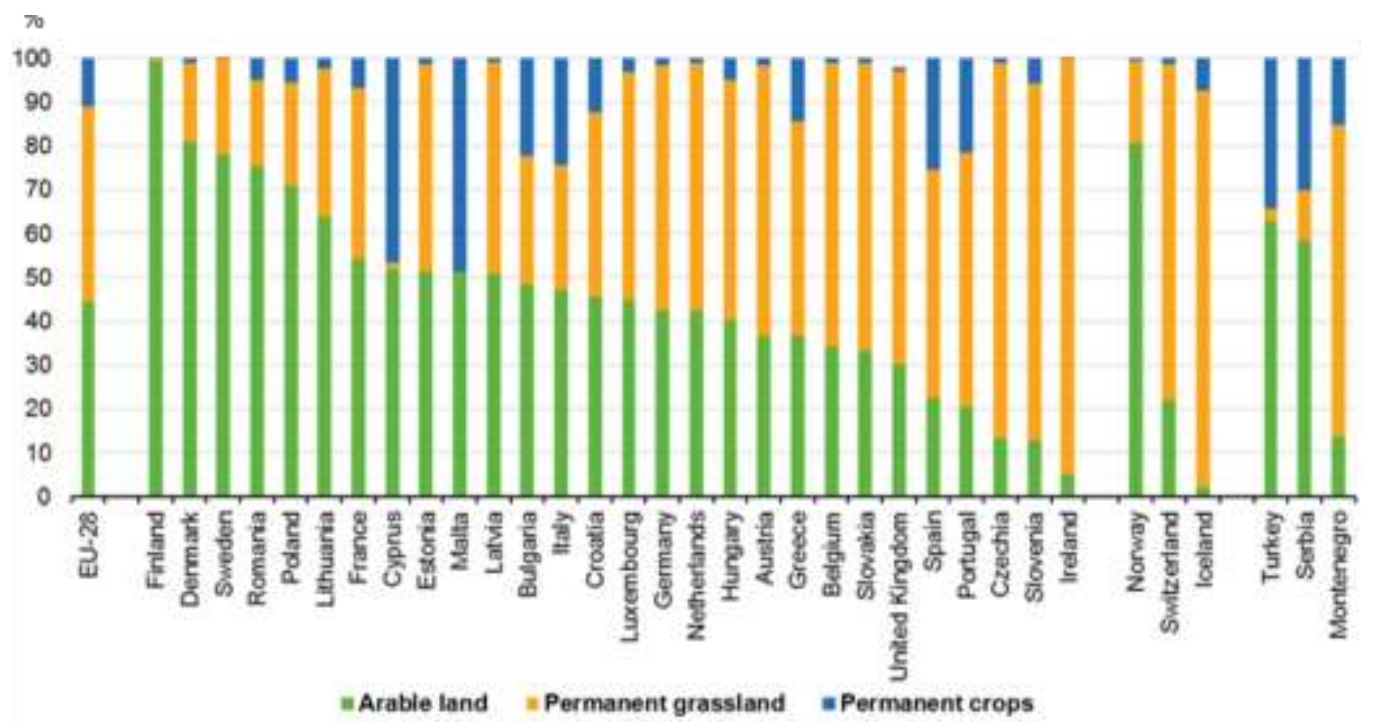

Source: Eurostat, 2019. (Online data code: org_cropar).

\subsubsection{Livestock: Number of Units of Types of Organic Livestock}

Organic animal production in Portugal has been expanding. The main livestock in organic farming in Portugal are sheep, bovine (i.e. cattle), poultry and apiculture. (DGADR, 2017, p.22, 37; DGADR, 2019). In 2017, the total organic livestock in Portugal included 99,281 sheep, 94,420 cattle, 55,522 beehives, and 46,729 birds. Although not numerically significant, pigs, goats and equines were also in organic production (Figure 11) (DGADR, 2019, p.14). 


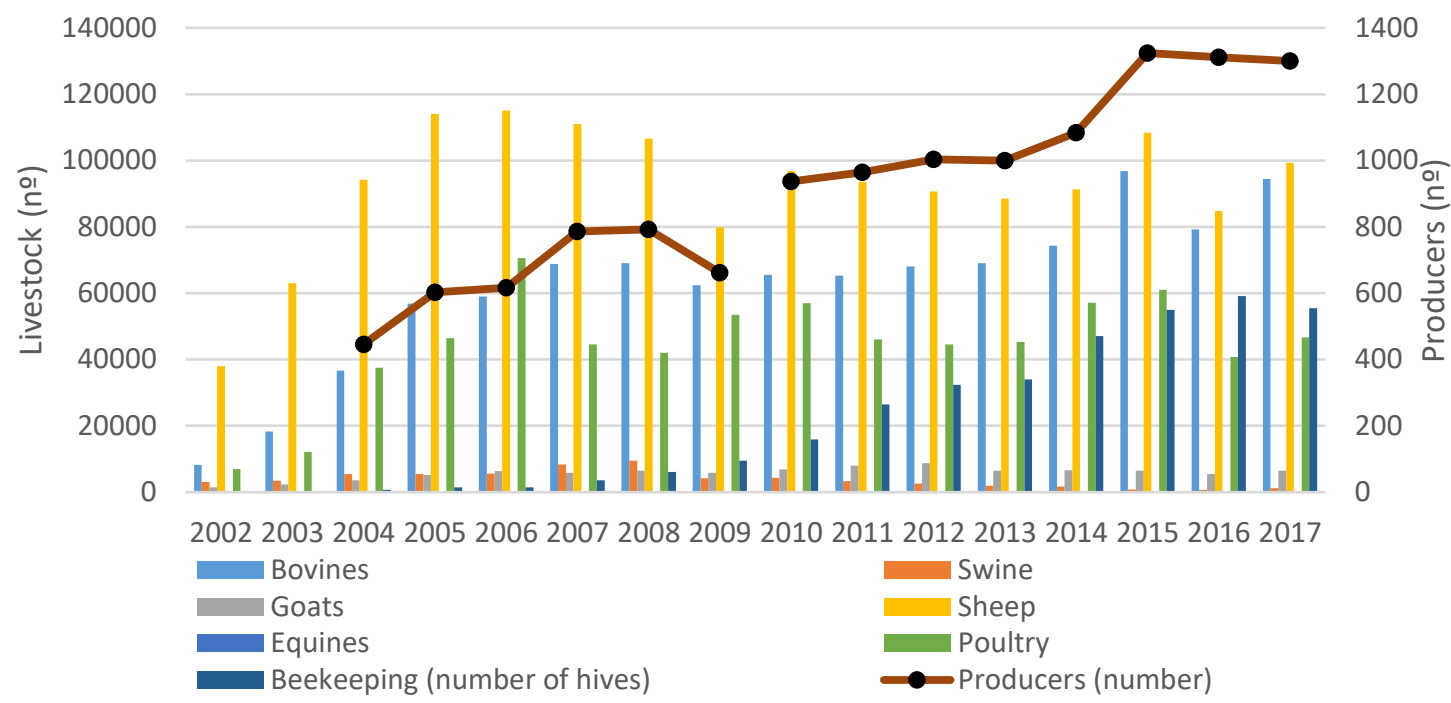

Source of data: DGADR, 2019. (Note: From 2010 onwards, the DGADR utilized a new methodology to calculate values; this is why there exists a break in the series).

Again, as with cultivated crops, livestock production varies greatly by region (Table 2).

Table 2: Total number of organic livestock in Portugal by type of species and by region (2017)

\begin{tabular}{|l|c|c|c|c|c|c|c|}
\hline ANIMAL SPECIES & Bovine & Swine & Goats & Sheep & Equines & Birds & Beekeeping \\
\hline AGRICULTURAL REGION & $\begin{array}{c}\text { No. of } \\
\text { heads }\end{array}$ & $\begin{array}{c}\text { No. of } \\
\text { heads }\end{array}$ & $\begin{array}{c}\text { No. of } \\
\text { heads }\end{array}$ & $\begin{array}{c}\text { No. of } \\
\text { heads }\end{array}$ & $\begin{array}{c}\text { No. of } \\
\text { heads }\end{array}$ & $\begin{array}{c}\text { No. of } \\
\text { beaks }\end{array}$ & No. of hives \\
\hline Entre-Douro e Minho & 3228 & 4 & 1818 & 374 & N/A & 1610 & 1999 \\
\hline Trás-os-montes & 1167 & 50 & 669 & 3212 & 1 & 36 & 38736 \\
\hline Beira Litoral & 408 & 35 & 426 & 66 & 1 & 21910 & 1275 \\
\hline Beira Interior & 17078 & 39 & 2076 & 31459 & 33 & 9000 & 6993 \\
\hline Ribatejo e Oeste & 8934 & N/A & 181 & 1017 & 3 & 12571 & 581 \\
\hline Alentejo & 63605 & 1027 & 1264 & 63153 & 61 & 1527 & 5714 \\
\hline Algarve & N/A & N/A & N/A & N/A & 10 & 75 & 224 \\
\hline Continental Portugal Total & $\mathbf{9 4 4 2 0}$ & $\mathbf{1 1 5 5}$ & $\mathbf{6 4 3 4}$ & $\mathbf{9 9} \mathbf{2 8 1}$ & $\mathbf{1 0 9}$ & $\mathbf{4 6 7 2 9}$ & $\mathbf{5 5 5 2 2}$ \\
\hline
\end{tabular}

Source of data: DGADR, 2019.

In 2017, taking a look at continental Portugal, the Alentejo had the largest number of livestock - cattle (63,605 heads; $67 \%$ of the total), sheep (63,153 heads; $64 \%$ of the total), and swine (1,027 heads; $89 \%$ of the total); the Beira Litoral the largest number of poultry $(21,910$ beaks); and Trás-os-Montes the largest number of beehives (38,736 hives; $70 \%$ of the total). This 
regional variation by type of livestock in production is visible in Figure 12 for the traditional Portuguese agricultural regions (DGADR, 2019, pp.15-16).

Figure 12: Composition of Animal Units in Organic Production by Agricultural Region in Continental Portugal, 2017

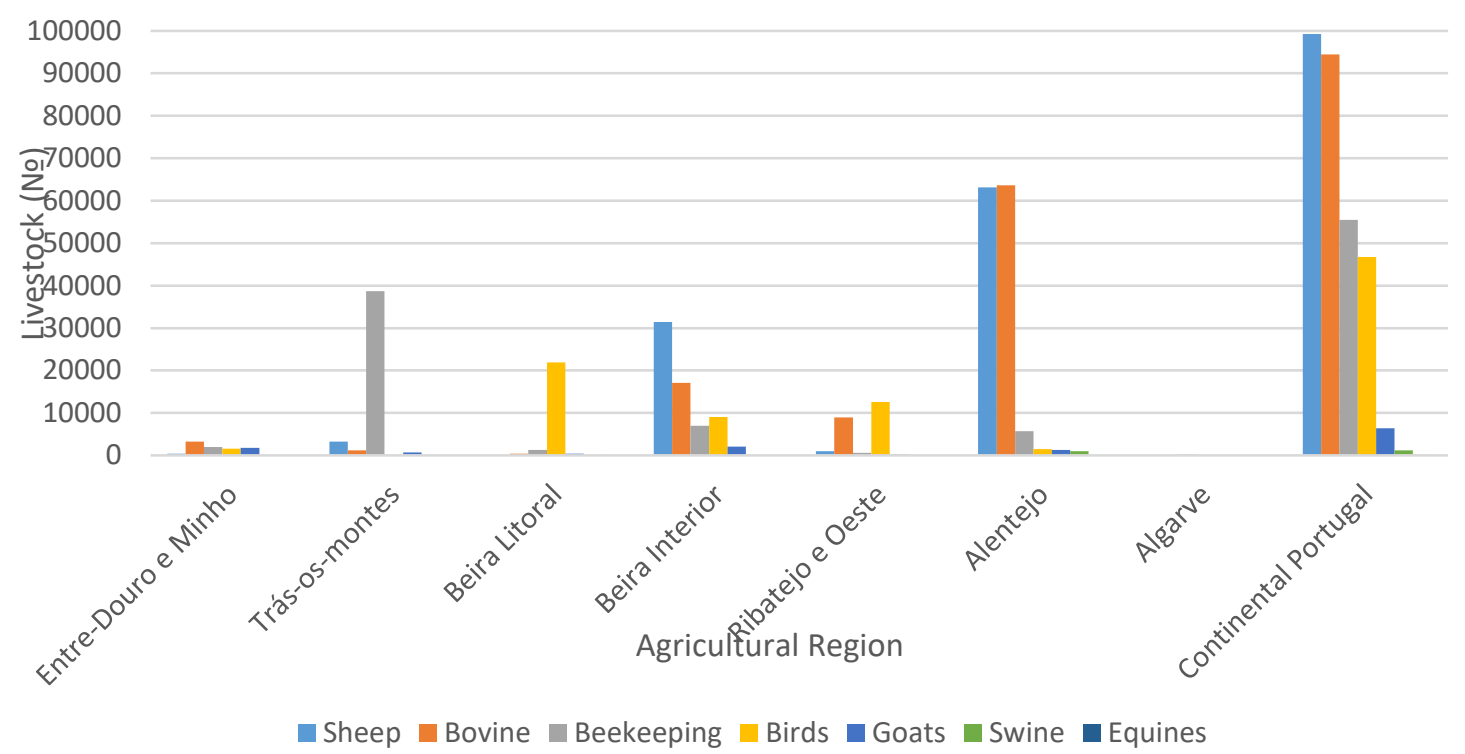

Source of data: DGADR, 2019.

In Portugal, swine production is not among its top 3 animals under organic production. It is apiculture, poultry production and goat production that lead the way and which all outweigh swine production (Eurostat, 2019).

Next, looking at the EU28, its organic livestock total is mostly made up of bovine, sheep and swine. In the EU28 in 2017, of the organic livestock animals, the majority included bovine, dairy cows, sheep, goats and poultry. The breakdown of these is visible in Table 3. 
Table 3: Total number of organic livestock by type in select EU28 member states (2017)

\begin{tabular}{|l|r|r|r|r|r|r|}
\hline $\begin{array}{c}\text { COUNTRY / ANIMAL } \\
\text { SPECIES }\end{array}$ & Live bovine & Dairy cows & Live swine & Live sheep & Live goats & $\begin{array}{c}\text { Live } \\
\text { poultry }\end{array}$ \\
\hline Germany & 788561 & 203958 & 193338 & 194241 & N/A & N/A \\
\hline France & 649856 & 128386 & 282286 & 602124 & 92874 & 735549 \\
\hline Italy & 336278 & 64855 & 61242 & 736502 & 115590 & N/A \\
\hline United Kingdom & 296172 & 77059 & 39100 & 889538 & 409 & 95575 \\
\hline Austria & 422008 & 115080 & 73302 & 119745 & 48017 & 414192 \\
\hline Denmark & 199870 & 70993 & 374963 & 10861 & 1663 & 953693 \\
\hline Netherlands & 65189 & 31883 & 87542 & 13321 & 42624 & 11020 \\
\hline Greece & 81425 & 12044 & 4434 & 935267 & 375514 & N/A \\
\hline Spain & 207121 & 8394 & 9938 & 590900 & 71741 & 22404 \\
\hline Portugal & 86881 & 51 & 1157 & 99328 & 6475 & 117 \\
\hline EU28 Total & $\mathbf{4 3 1 0 7 4 0}$ & $\mathbf{8 7 7} \mathbf{7 5 0}$ & $\mathbf{1 2 0 2 7 7 7}$ & $\mathbf{4 9 4 8 3 1 1}$ & $\mathbf{8 0 8 5 8 1}$ & N/A \\
\hline
\end{tabular}

Source of data: Eurostat, 2019. (Data reference code: Organic livestock (from 2012 onwards) - (org_lstspec), (apro_mt_lscatl), (apro_mt_lspig), (apro_mt_lsgoat) and (apro_mt_lssheep).

\subsection{Number of producers}

In Portugal, the number of agricultural producers has been steadily increasing. In 2018, according to Eurostat, there were 4,674 registered agricultural producers in Portugal. Moreover, there were 760 processors, 22 importers, and 2 aquaculture producers (Eurostat, 2019).

The main producers in Portugal, in 2017, were those involved with: food industries; slaughter houses, preparation and preservation of meat and meat products; preparation and conservation of fish, crustaceans and molluscs; preparation and preservation of horticulture products (fruits and vegetables); production of animal and vegetable oils and fats; the dairy industry; processing of cereals and pulses; manufacture of starches and related products; manufacture of bakery and other flour products; manufacture of other food products; manufacture of prepared animal feed; the beverage industry; and the wine industry (DGADR, 2019).

Next, taking a look at the EU28 for the year 2017, according to Eurostat, the total number of registered organic operators for the EU28 as whole was not available. However, leading the way was Italy with 66,788 , Spain with 37,712 , France with 36,691, and Germany with 29,764 organic operators. Portugal ranked 10th with 4,674 organic operators in 2017 , while the UK ranked 18th with 3,479 organic operators (Eurostat, 2019).

Globally, FiBL estimates that the number of organic producers worldwide has been on the rise each year since the year 2000 (252,595). This has resulted in an increase of $1,232.8 \%$ for the period $2000-2017$, reaching 3,113,875 organic producers (2017) (FiBL, 2019). Leading the way is Asia - 1,403,139 (2017), Africa - 806,899 (2017), Latin America - 457,044 (2017), Europe - 397,509 (the EU - 305,394) (2017), Oceania - 26,750 (2017) and North America - 22,966 
(2017) (The USA -18,166; Canada - 4,800 (2017) (note: FiBL values may differ from Eurostat and other sources as they are collected independently and by using different methods via their global survey on organic farming, in which numerous experts from more than 180 countries contribute to the data collection). (FiBL, 2019).

\subsection{Organic retail sales}

Overall, it is roughly estimated (based on a non-extensive survey) that Portugal's organic retail sales have totalled approximately 21 million Euros annually from 2009-2017 (FiBL, 2019). Thus, the growth trend has been without any great changes in pattern in recent years (INE, 2019). Most of the activity in Portugal is lying within the sector of industrial transformation (INE, 2019). Three regions - North, Centre, and the AML (Lisbon Metropolitan Area) - are leading the way by accounting for most of the sales of organic products in Portugal (INE, 2019).

Comparing Portugal to the EU28, the country is not a frontrunner in terms of retail sales, as currently it is outside the top ten. In fact, according to FiBL for the years 2011-2017, Portugal retained not even $1 \%$ of the EU's total organic retail sales market share with approximately $0.20 \%$ of the total (Figure 13) (FiBL, 2019).

Figure 13: Total Value of Organic Retail Sales for top countries in Europe in millions of Euros (€), 2018

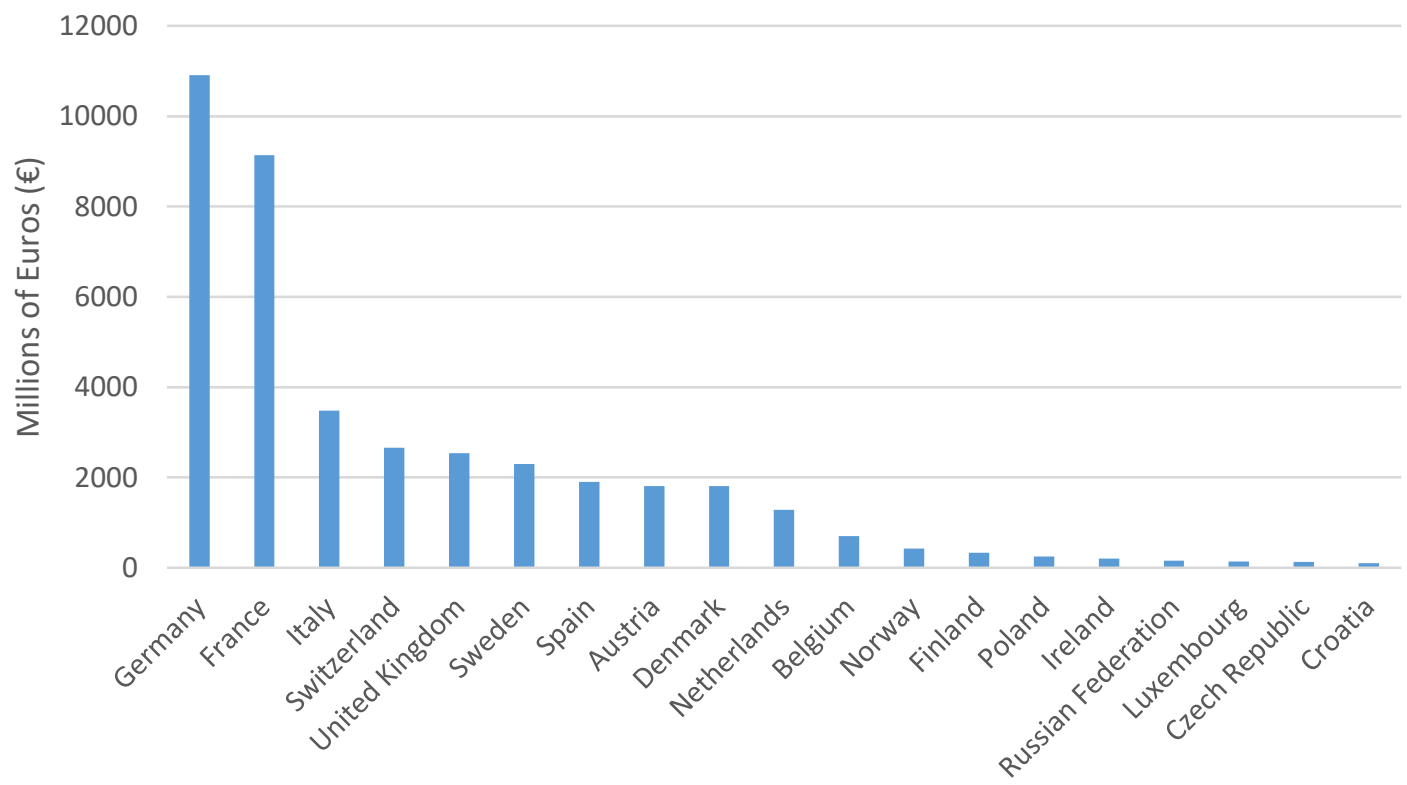

Source of data: FiBL, 2019. (Link: https://www.organic-world.net/statistics/maps.html). 
Europe's total value of organic retail sales slightly more than doubled from 2009-2017, as did those of the EU28 (Figure 14) (FiBL, 2019).

Figure 14: The European Union's Total Value of Organic Retail Sales (in Billions of Euros), 20002018

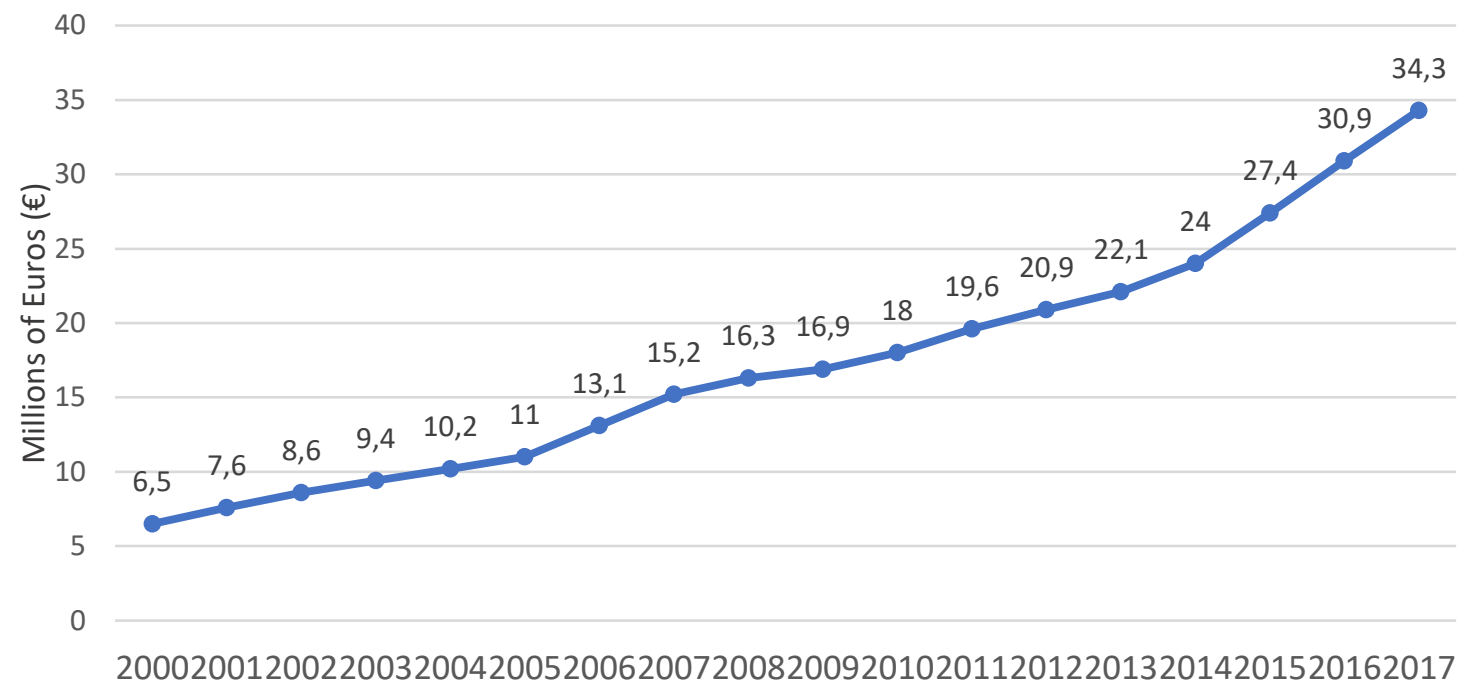

Source of data: FiBL, 2019. (Link: https://www.organic-world.net/statistics/maps.html).

Globally, the amount of retail sales of organic products has also been continually increasing, as it more than doubled from 2009 to 2017 (FiBL, 2019). Although exact figures are not available, FiBL estimates that retail sales in 2017 (in millions of Euros - $€$ ) by continent/region were: World - 92,488.50, North America - 43,012.19 (The U.S.A. - 40,010.62), Europe 37,768.11 (The EU28 - 34,711.66), Asia - 9,589.53, Oceania - 1,293.08, Latin America - 809.68 and Africa - 15.90 (FiBL, 2019).

\subsection{Imports}

Import volumes have increased in Portugal over the last decade. This rise was linked to the granting of more import licenses for importers wanting to import products into Portugal. This increase in the number of importers led to an increase in quantities imported (a 732\% increase) from 2014 to 2016 (Table 4) (DGADR, 2017, p.40). 
Table 4: Total Volume (in kilograms - kg) and total number of Importers (2014, 2015, 2016)

\begin{tabular}{|l|c|c|c|c|}
\hline \multirow{2}{*}{ UNIT } & \multicolumn{3}{|c|}{ YEAR } & \multirow{2}{*}{ VARIATION } \\
\cline { 2 - 5 } & $\mathbf{2 0 1 4}$ & $\mathbf{2 0 1 5}$ & $\mathbf{2 0 1 6}$ & \\
\hline Quantity imported (kg) & 46674 & 45870 & 388181 & $732 \%$ \\
\hline Number of Importers & 4 & 6 & 9 & $125 \%$ \\
\hline
\end{tabular}

Source of data: DGADR, 2019.

With respect to imported organic products, the largest amount was imported from China (43\%), Ecuador (33\%), Israel (8\%) and Chile (7\%) (DGADR, 2017, p.40). Combined, China and Ecuador accounted for about $\mathbf{7 6 \%}$ of the total volume imported into Portugal $(480,725 \mathrm{~kg})$ from 2014 to 2016 (Figure 15) (DGADR, 2017, p.40).

Figure 15: Source countries and quantity of organic products $(\mathrm{kg})$ that were imported into Portugal in 2016

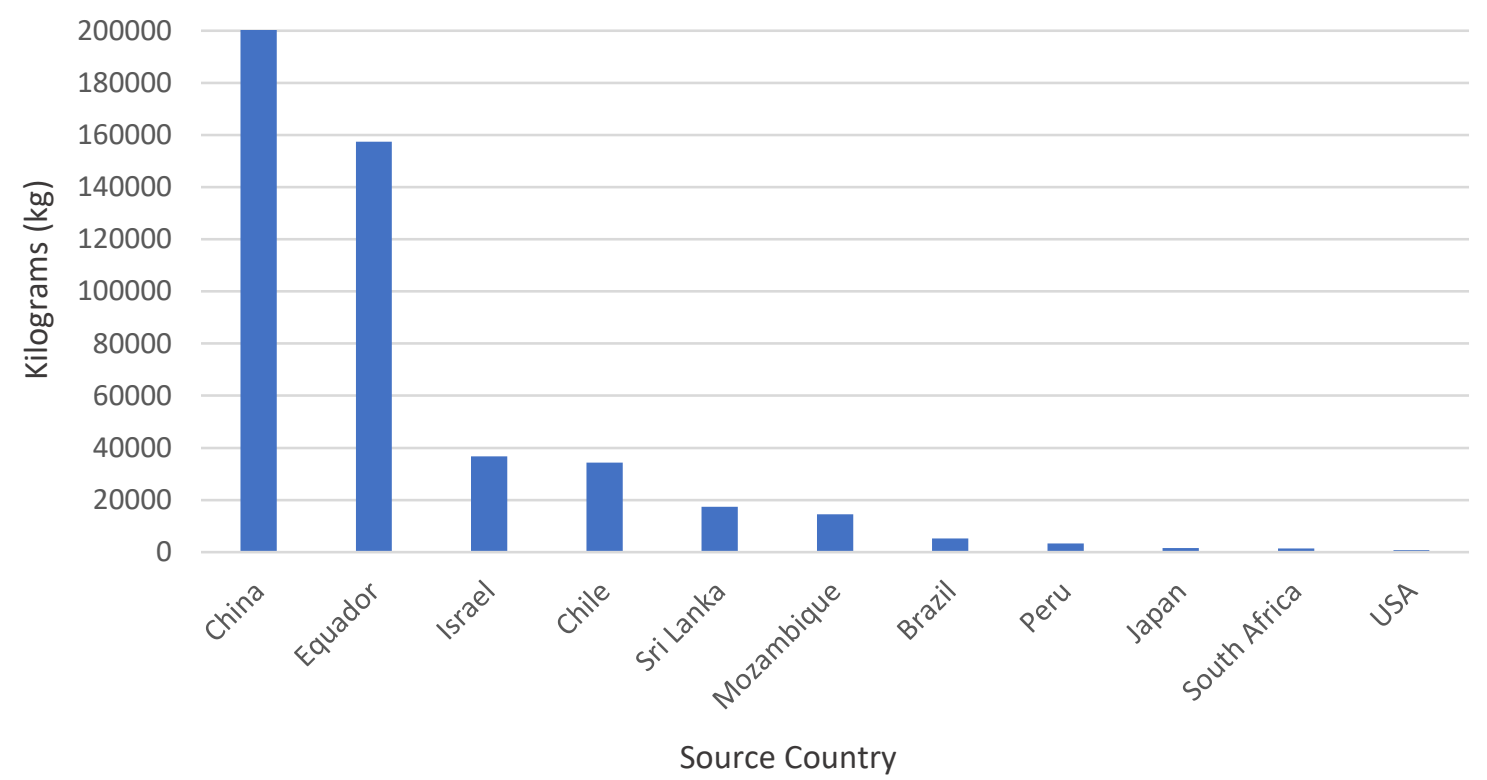

Source of data: DGADR, 2019. (Note: No information is available on monetary values). 
Furthermore, from 2014 to 2016, the categories of imported products that led were Fruits and Vegetables (49\% of the total), Cereals and Legumes (43\%), Oils and Fats (7\%) and Other products (1\%) (Table 5) (DGADR, 2017, p.41).

Table 5: Quantity of organic products imported into Portugal by Category - years 2014 to 2016

(kilos)

\begin{tabular}{|c|c|c|c|c|c|}
\hline & \multicolumn{3}{|c|}{ QUANTITY (kg) } & \multirow{2}{*}{$\begin{array}{c}3 \text { YEAR } \\
\text { TOTAL } \\
(\mathbf{k g}) \\
\end{array}$} & \multirow{2}{*}{$\begin{array}{c}2016 \\
\text { TOTAL } \\
(\%)\end{array}$} \\
\hline FOOD PRODUCT & 2014 & 2015 & 2016 & & \\
\hline Fruit and Horticulture & 6651 & 15580 & 214471 & 236702 & $49 \%$ \\
\hline Cereals and Legumes & 40000 & 22166 & 146432 & 208598 & $43 \%$ \\
\hline Oils and Fats & 0 & 6009 & 25845 & 31854 & $7 \%$ \\
\hline Other Food Products & 23 & 2115 & 1433 & 3571 & $1 \%$ \\
\hline Total & 46674 & 45870 & 388181 & 480725 & $100 \%$ \\
\hline
\end{tabular}

Source of data: DGADR, 2019. (Note: No information was available on monetary values).

\section{BARRIERS}

The organic sector faces numerous barriers that are hindering a faster transformation. Difficulties for the sector are elaborated on below.

i) Product placement: although large supermarket chains have increased visibility and placement of organic products in their stores, Portugal with its high number of SMEs, has many stores that offer no organic products (Truninger, 2010, p.97, 100; Matos et al, 2016).

ii) A disconnect between production, distribution and marketing systems: geographical disparity exists as most organic farms are located inland in rural areas (e.g. Alentejo \& Beira Interior held 79\% in 2017) (DGADR, 2017; 2019; Matos et al, 2016). Big "organic plots are located deep inland" (Ribeiro et al, 2015, p.23). Producers must distribute products far distances to densely populated urban regions where markets exist (i.e. The North, Central, and AML regions). As a result, inland regions remain underdeveloped, less populated and with low demand (Truninger, 2010, p.100; Garrancho, 2013). Offer is sparse, scattered and irregular because farms are small and lack organization of production and thus cannot guarantee regularity in supply (Matos et al, 2016). Also, farmers are lacking specialized marketing channels for their organic products (Matos et al, 2016, p.26; Dentinho, 2016, p.19; INE, 2019). Supply chain constraints (e.g. certification costs, lower margins, lack of promotional support) remain an obstacle that producers are not supported to overcome (Dentinho, 2016). Changing the production system requires a change in behaviour by both producers and consumers (Ribeiro et al, 2015, p.18). 
iii) High transport costs: Distribution is quite costly because the domestic production market is insufficient, dispersed and disorganized. Consumers must pay higher prices for organic products at retail outlets as a result. Products must travel large distance to the main consumer centres also raising costs (Truninger, 2010, p.100, 117, 118; Matos et al, 2016, p.26).

iv) Competition from imports: Portugal relies heavily on imports, as domestic supply is insufficient to meet domestic demand (growing consumer demand and stagnation of national production allows imports to grow). These imported products (mainly processed) are overpriced due to added supply costs and act as a barrier to the growth of the sector nationally (Truninger, 2010; Dentinho, 2016, p.4; DGADR, 2017, p.40-41). Imports fill the void for organic processed food products, as there are not yet processing industries in Portugal to make these (Ribeiro et al, 2015, p.22).

v) European subsidies focused on extensive crops: while organic producers are highly dependent on financial support policy (EU and national), the majority of European subsidies that support conversion to organic farming have primarily focused on extensive crops (pastures, olive groves, and arable crops). This is problematic, as certain crops (and regions) are favoured over others. As a result, a few crops account for the majority (e.g. permanent pastures (58\%), forage crops (14\%) and dried fruits (9.7\%) (2017)), leaving the sector with a low diversity of crops and products (DGADR, 2019, p.12 and p.19; Matos et al, 2016, p.26). In addition, livestock farmers take the majority of area support funds. However, when they are unable to pay for high cost certified organic animal feed, they sell their livestock in conventional channels (non-livestock focused types of production have more production costs but receive little to no financial support) (Dentinho, 2016, p.19). In the past, "area driven payments" have mostly benefited large landowners who were farming livestock in a traditional "nearly organic" way and were able to claim subsidies for area expansion as an extra profit, thereby taking support payments away from other organic farmers (Ribeiro et al, 2015, p.25).

vi) The substantial growth in the area of pasture to the detriment of other crops. An intensive agriculture model (of large-scale livestock production - bovine, sheep, poultry, and apiculture and monocultures needed to support it) is being promoted. This ensures that pastureland dominates. The European animal production legislation promoted conversion to extensive crops such as pastures for livestock production. In $2017,72 \%$ of the area in organic mode was pasture and fodder to feed livestock, while just $26 \%$ of the area was intended for the production of food products to be directly consumed or transformed (DGADR, 2017, p.22; Truninger, 2010; Ribeiro et al, 2015; Dentinho, 2016; DGADR, 2019).

vii) Products that are in demand are being neglected by Portuguese producers. There exists an imbalance between supply and demand of the most desired organic products - vegetables, fresh 
fruits, milk, meat and derivatives. Fresh fruit and vegetables are the most sought-after and sold. The lack of these leads to many being imported. Portuguese producers neglect these as they require greater technical knowledge, management skills, support, labour costs (require more time for monitoring and preventative actions) and expertise. In addition, many fruit and vegetable farms often possess small production volumes (Truninger, 2010; Garrancho, 2013; Matos et al, 2016).

viii) Lack of adequate support and market expertise for national producers: Many farmers often lack education and training to overcome insufficient professionalism in negotiating with large retail chains; lack of technical support; insufficient consistency in the quality of products and packaging; and different quality expectations for organic products. Also, there is: a lack of national producers of organic seeds; incipient marketing strategies (which make their products unsellable or untradeable); a lack of consistency in deliveries; a poor diversity and quantity of organic foods; a lack of organic production inputs and a lack of structural organization in the sector (Costa et al, 2003, p.13 in Truninger, 2010, p.112-113; Matos et al, 2016, p.26; Dentinho, 2016, p.16). Farmer's lack of marketing competences is a main constraint to the expansion of organic production as the market is still small and fragile (Matos et al, 2016).

ix) The hybrid configuration of the sector: a double trajectory of the organic farming movement exists in Portugal, as there is a group of producers and retailers that are linked to the pioneers of the movement and therefore defend its core values; and a second group of professional producers and companies that have focused on directing their products to the export market, the retail market, the specialty food market, and to health food stores. Therefore, these two movements form a complex hybrid sector, as they mix together production and market elements (Truninger, 2010, p.117-118; Ribeiro et al, 2015, p.19). The character of Portugal's agro food sector - mostly made up of traditional extensive agricultural systems - acts as a barrier as consumers often believe that traditional systems are very similar to organic production systems. Therefore, they do not feel a need to seek organic products that are stamped as certified out of the belief that they will not benefit farmers financially nor will be of better food quality (Ribeiro et al, 2015, p.24).

x) Product price: organic product prices are high for the consumer and do not reflect the producer's costs (application process, increased workload, increased management). As a result, high priced organic products become accessible only to a minority of the population (e.g. middle class) thereby creating a price barrier and holding back consumption growth (Matos et al, 2016, p.26; Garrancho, 2013). Farms are often small, resulting in producers being unable to meet retailer production level demands, thus impairing their market entrance, reducing their bargaining power, and lowering their margins (Dentinho, 2016, p.17-18). Certification is often costly and too 
expensive for small scale farmers - the majority of organic producers in Portugal (Ribeiro et al, 2015, p.24).

\section{CONCLUSIONS}

In conclusion, this paper aimed to contribute to an overall critical assessment of the Portuguese organic sector's features and evolution, to stress the multiplicity of elements that are contributing to the agro-food system's transformation into a more sustainable one, and to identify some of the main obstacles that need to be overcome to boost the sustainability transition of the agro-food system in Portugal.

In order to achieve these aforementioned aims, this paper has built upon the multi-level perspective (MLP) by employing a whole systems analysis of organic agriculture in Portugal. The analysis defended an integrated vision of the systems, where multiple interactions occur within the niche, regime and landscape levels. Three extensions of the MLP-logic to conceptualize whole system reconfiguration of the agro-food system were employed: 1) Multiple landscape dynamics differentially affect agro-food regimes; 2) Internal agro-food regime dynamics are affected by multi-regime interactions; and 3) Multiple niche-innovations may affect agro-food regimes through different mechanisms.

In Portugal, over the last few decades, the organic agriculture sector has experienced growth in terms of production, number of producers, amount of retail sales, imports and exports. This growth, however, has been slow. While numerous drivers have been responsible for this growth, numerous barriers have slowed down the transition to more organic production. The growth that has occurred varies greatly by region and has been unevenly distributed amongst the agricultural regions. Also, a lack of domestic production of organic products has led to an increase in imported organic products.

This paper has found that organic agriculture, as a sustainable agriculture niche-innovation, is still not greatly contributing to overall agricultural production. The fact that there exists a low supply of organic products, despite its ever-increasing demand, suggests that a transition to increased organic production requires a deeper system reconfiguration, where an array of distinct policies are mobilized and a diversity of actions take place at different levels (Geels, 2018; Pe'er et al, 2019). 


\section{REFERENCES}

Belz, F.M. (2004). A transition towards sustainability in the Swiss agri-food chain (1970-2000): Using and improving the multi-level perspective. System Innovation and the Transition to Sustainability, in System Innovation and the Transition to Sustainability Theory, Evidence and Policy (2004). Edited by Boelie Elzen, Frank W. Geels and Ken Green. Edward Elgar Publishing Ltd. Cheltenham UK; Northampton, MA, USA (97-113).

Dentinho, M. (2016). Organic Farming in Portugal. The Impact of Public Measures. NOVA School of Business and Economics, 1-24.

Garrancho, J. (2013). Organic Agriculture in the Algarve. Eco123. Link: http://econ123.info/en/portugal-en/report-en/organic-agriculture-in-the-algarve/.

Geels, F.W. (2018). Low-carbon transition via system reconfiguration? A socio-technical whole system analysis of passenger mobility in Great Britain (1990-2016). Energy Research \& Social Science, 46, 86-102.

Matos, A., Cabo, P., Ribeiro, M.I. \& Fernandes, A. (2016). Résumé: Two decades of organic farming in Portugal. FONCI MED 2016. Gouvernance responsable des régimes fonciers. Instituto Politécnico de Bragança, Portugal.

Pe'er, G., Zinngrebe, Y., Moreira, F., Sirami, C., Schindler, S., Müller, R., Bontzorlos, V., Clough, D., Bezák, P., Bonn, A., Hansjürgens, B., Lomba, A., Möckel, S., Passoni, G., Schleyer, C., Schmidt, J. \& Lakner, S. (2019). A greener path for the EU Common Agricultural Policy. Science, Vol. 365 Issue 6452, 449-451.

Ribeiro, S.C.; Martins, J. \& Pereira, H. (2015). Pathways project. Exploring transition pathways to sustainable, low carbon societies. Grant Agreement number 603942. Deliverable D2.1: Analysis of green niche-innovations and their momentum in the two pathways. Country report 9: Green niche-innovations in the Portuguese agro-food system, 1-52.

Truninger, M. (2010). O Campo Vem à Cidade: Agricultura biológica, Mercado e consumo sustentável, Lisboa, Imprensa de Ciências Sociais.

\section{Online Sources}

DGADR (2019). Ministério da Agricultura, Florestas e Desenvolvimento Rural: Direção-Geral de Agricultura e Desenvolvimento Rural (DGADR).

Eurostat (2019). Organic farming statistics. 
European Union/European Commission:

https://ec.europa.eu/research/participants/data/ref/h2020/wp/2018-2020/main/h2020-wp1820-

food_en.pdf

https://ec.europa.eu/info/sites/info/files/food-farming-fisheries/key_policies/documents/cap-

post-2020-environ-benefits-simplification_en.pdf

https://ec.europa.eu/info/sites/info/files/food-farming-fisheries/farming/documents/organic-

action-plan_en.pdf

FiBL (2019). The Research Institute of Organic Agriculture.

GPP (2019). Gabinete de Planeamento e Políticas do Ministério da Agricultura, Mar, Ambiente e Ordenamento do Território.

INE (2019). Instituto Nacional de Estatística (INE). 